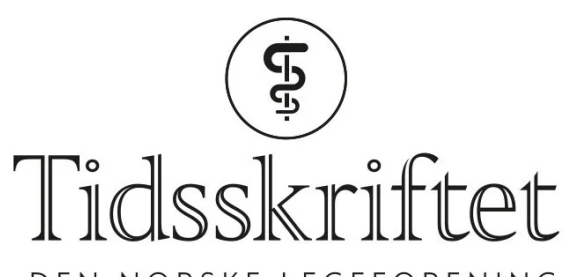

DEN NORSKE LEGEFORENING

\title{
Slik får biologiske legemidler navn
}

SPRÅKSPALTEN

\section{PETTER GJERSVIK}

petter.gjersvik@medisin.uio.no

Petter Gjersvik er dr.med., professor ved Universitetet i Oslo, medisinsk redaktør i Tidsskriftet og redaktør for språkspalten.

\section{OLAV SUNDNES}

Olav Sundnes er ph.d., overlege ved Seksjon for hudsykdommer ved Oslo universitetssykehus og universitetslektor ved Universitetet i Oslo.

Biologiske legemidler med monoklonale antistoffer har lange generiske navn som kan virke kompliserte og forvirrende. 


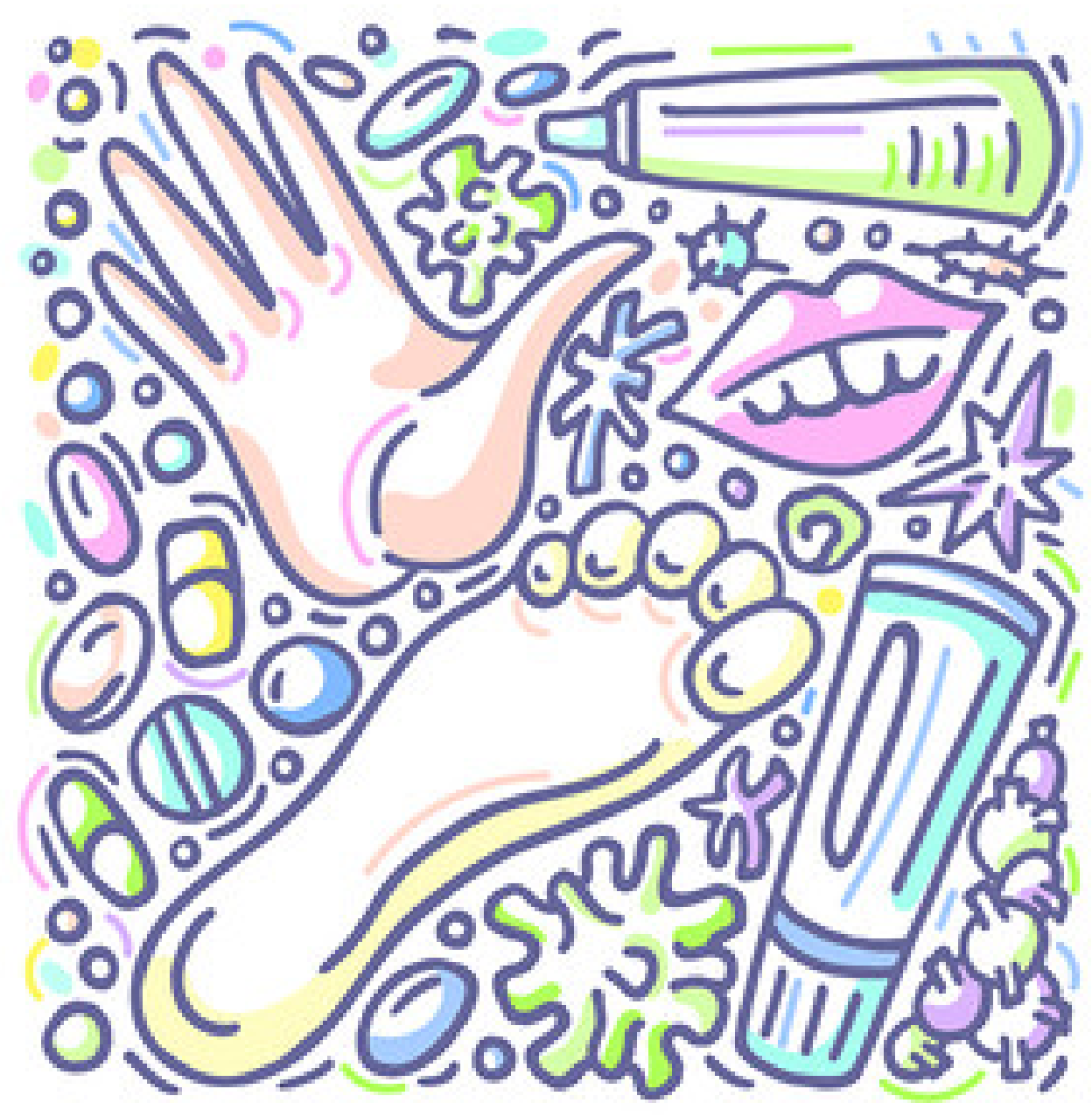

Illustrasjon: undefined undefined / iStock

Pasienter med inflammatorisk sykdom i tarm, ledd eller hud blir i økende grad behandlet med biologiske legemidler (1). Dette dreier seg i hovedsak om monoklonale antistoffer rettet mot sentrale punkter i inflammatoriske prosesser. Det finnes også monoklonale antistoffer mot kreft, infeksjoner og kardiovaskulære sykdommer.

Monoklonale antistoffer er store og komplekse molekyler med affinitet til spesifikke molekylære strukturer, slik som tumornekrosefaktor, cytokiner eller cytokinreseptorer. Den molekylære strukturen av antistoffene kan variere noe, men variasjonen må være innenfor spesifikke grenser. Dette skiller biologiske legemidler fra konvensjonelle legemidler, der virkestoffet er relativt små molekyler som har identisk struktur, og som fremstilles syntetisk. Nye monoklonale antistoffer utvikles nå i økende tempo, inkludert biotilsvarende legemidler med tilnærmet samme struktur som originalpreparatet, men med likeverdige biologiske og kliniske effekter.

Monoklonale antistoffer har lange generiske navn som kan virke kompliserte og forvirrende (1). Salgsnavn uten assosiasjoner til det generiske navnet gjør det ikke lettere. Hva er logikken bak disse navnene?

\section{Regler for navnsetting}

Verdens helseorganisasjon (WHO) har utarbeidet retningslinjer for hvordan monoklonale antistoffer og andre stormolekylære virkestoffer skal navnsettes, første gang i 2011 og senere med revisjoner (2). Disse retningslinjene klargjør hvordan generiske navn skal settes opp 
på en måte som reflekterer molekylets struktur, opphav og virkningsmåte. De generiske navnene er bygget opp av fire bokstavgrupper (tabell 1) (2, 3): prefiks + bokstavgruppe A + bokstavgruppe B + suffiks.

\section{Tabell 1}

Eksempler på monoklonale antistoffer mot psoriasis $(2,3)$.

\begin{tabular}{|lll|}
\hline Generisk navn & Bokstavgrupper & Salgsnavn \\
\hline infliximab & inf-li-xi-mab & Remicade, Remsima, Inflectra, Zessly, Flixabi \\
\hline adalimumab & ada-lim-u-mab & Humira, Hyrimoz \\
\hline ustekinumab & uste-kin-u-mab & Stelara \\
\hline secukinumab & secu-kin-u-mab & Cosentyx \\
\hline ixekizumab & ixe-ki-zu-mab & Taltz \\
\hline brodalumab & broda-l-u-mab & Kyntheum \\
\hline tildrakizumab & tildra-ki-zu-mab & Ilumetri \\
\hline guselkumab & gusel-k-u-mab & Tremfya \\
\hline risankizumab & risan-ki-zu-mab & Skyrizi \\
\hline
\end{tabular}

Prefikset, også omtalt som fantasinavnet, består gjerne av to til seks bokstaver og skal fremstå som lesbart, unikt og annerledes enn prefikset på andre monoklonale antistoffer.

Bokstavgruppe A skal angi strukturen eller prosessen som det monoklonale antistoffet er rettet mot. For midler mot inflammatorisk sykdom vil dette være - $k$ - eller -ki-for interleukiner (cytokiner) og -i- eller -li-for immunmodulering. En bestemt konsonant eller vokal kan legges til for å gjøre navnet lettere å uttale (tabell 1 ).

Bokstavgruppe B skal angi kilden for det monoklonale antistoffet - enten humant eller animalsk vev. Infikset - $u$ - står for humant, -o-for murint (mus), - xi- for kimært og - $z u$ - for humanisert antistoff. I kimære antistoffer er hele den variable regionen i antistoffet fra dyr, mens det i humaniserte kun er små deler av den variable regionen som er fra dyr.

Suffikset -mab angir at det dreier seg om et monoklonalt antistoff(av engelsk monoclonal antibody).

Med disse byggesteinene ser vi at for eksempel infliximab består av inf-(fantasinavn), -li(bokstavgruppe A), -xi-(bokstavgruppe B) og -mab (suffiks) (tabell 1). I Norge har Felleskatalogen endret skrivemåten for enkelte bokstavkombinasjoner, bl.a. xi til ksi, slik at man på norsk (og i Tidsskriftet) kan skrive infliksimab (3).

Et annet monoklonalt antistoff mot inflammatorisk sykdom, certolizumab pegol, har fått et ekstra ledd. Dette angir at stoffet er pegylert, noe som kan redusere degradering, overgang til placenta og kanskje immunogenisitet (4).

\section{Nye regler fra 2017}

I 2017 bestemte komiteen i WHO å droppe bokstavgruppe B for nye monoklonale antistoffer (5). Begrunnelsen var bl.a. at navnene ble tiltagende lange og vanskelige å uttale, og at monoklonale antistoffer med visse bokstaver eller bokstavkombinasjoner kunne bli 
oppfattet som immunologisk mer fordelaktige enn andre (5). Monoklonale antistoffer med navn uten bokstavgruppe B er nå under utprøving mot inflammatoriske hudsykdommer, bl.a. spesolimab (ㅁ), altså speso-(fantasinavn), -li- (bokstavgruppe A) og -mab (suffiks).

I USA godkjennes biotilsvarende legemidler med et ekstra suffiks i virkestoffnavnet for å skille dem fra originalpreparatene. Dette gjelder bl.a. adalimumab, som har blitt gitt suffikser som -atto, - $a d b m$, - $a d a z$, -bwwd og -afzb (7.). I Norge og Europa, derimot, praktiseres dette ikke (3,, ) .

\section{Salgsnavn}

Som salgsnavn velger produsenten ofte et navn som ikke har noen likhet med det generiske navnet (tabell 1) (3). Salgsnavnet må være unikt og helst vekke positive assosiasjoner. Hensikten er å bygge opp et merkevarenavn og få en sterk markedsposisjon, slik at pasienter og leger viser lojalitet til produktet.

\section{LITTERATUR}

1. Peters GL, Hennessey EK. Naming of biological products. US Pharm 2020; 45:33-6.

2. World Health Organization. Guidance on the use of international nonproprietary names (INNs) for pharmaceutical substances. https://www.who.int/medicines/services/inn/innguidance/en/ Lest 23.11.2020.

3. Felleskatalogen. https://www.felleskatalogen.no. Lest 23.11.2020.

4. Pasut G. Pegylation of biological molecules and potential benefits: pharmacological properties of certolizumab pegol. BioDrugs 2014; 28 (suppl 1): S15-23. [PubMed][CrossRef]

5. World Health Organization. Revised monoclonal antibody (mab) nomenclature scheme. INN Working Doc. 17.416.

https://www.who.int/medicines/services/inn/Revised_mAb_nomenclature_scheme.pdf\#: :text=Revi sed\%2omonoclonal\%2oantibody\%20\%28mAb\%29\%2onomenclature\%20scheme\%2oInternational\%20No nproprietary,that\%2ois\%2oglobally\%2orecognized\%20and\%2ois\%2opublic\%2oproperty. Lest 23.11.2020.

6. Ratnarajah K, Jfri A, Litvinov IV et al. Spesolimab: A novel treatment for pustular psoriasis. J Cutan Med Surg 2020; 24: 199-200. [PubMed][CrossRef]

7. US Food \& Drug Administration. Biosimilar product information.

https://www.fda.gov/drugs/biosimilars/biosimilar-product-information Lest 23.11.2020.

8. European Medicines Agency. https://www.ema.europa.eu/en/ Lest 23.11.2020.

Publisert: 9. februar 2021. Tidsskr Nor Legeforen. DOI:10.4045/tidsskr.20.0995

(C) Tidsskrift for Den norske legeforening 2023. Lastet ned fra tidsskriftet.no 26. april 2023. 